\title{
What factors influence colonization of lichens, liverworts, mosses and vascular plants on snags?
}

\author{
M. Staniaszek-Kik ${ }^{1} \cdot$ D. Chmura $^{2}$ (D) J. Żarnowiec ${ }^{2}$ \\ Received: 4 October 2018 / Accepted: 4 January 2019 / Published online: 11 February 2019 \\ (C) The Author(s) 2019
}

\begin{abstract}
The dead standing trees i.e. snags are known as habitat for epiphytic and epixylic species including first of all lichens and bryophytes. The vascular plants are much rarer on this type of coarse woody debris (CWD). The eighty snags (CWD elements higher than $1.5 \mathrm{~m}$ ) of Norway spruce Picea abies and beech Fagus sylvatica in the Karkonosze Mts. were examined for the presence of lichens, liverworts, mosses and vascular plants. The height of snags, their decomposition stage, cover of bark, diameter at breast height (DBH) as well as site conditions (elevation, slope and aspect, presence in forest community) were measured and noted. The percent cover of plants and lichens were estimated on each snag. Totally 99 taxa were recorded. There lichen species were dominant (44), followed by mosses (34), liverworts (13) and there were only 8 vascular plants. The total species richness varied from 1 to 22 taxa. The species composition growing on snags was subjected to canonical correspondence analysis and statistical analyses. They revealed that the species identity of snag is one of the most important factors influencing species composition. The number of species is positively correlated with DBH whereas decomposition stage, presence of bark, snag height are not significant factors. The species richness increases also with altitude what is connected with higher abundance of spruce snags. The occurrence of snags in this area is mainly associated with forest management practices in the past. Despite of some observed patterns in colonization of snags they are important habitat especially for lichens.
\end{abstract}

Keywords Biodiversity $\cdot$ Epixylic bryophytes $\cdot$ Forest condition $\cdot$ Standing deadwood

\section{Introduction}

Snags i.e. standing dead trees are along fallen trees $(\operatorname{logs})$ and stumps component of so called coarse woody debris (CWD). In contradiction to the remaining CWD elements they are not so frequent and do not catch such high interest of researchers (Angers et al. 2012). The snags are known as important habitat for nesting birds (Zarnowitz and Manuwal 1985; Drapeau

\section{Chmura}

dchmura@ath.bielsko.pl

M. Staniaszek-Kik

kik@biol.uni.lodz.pl

J. Żarnowiec

jzarnowiec@ath.bielsko.pl

1 Department of Geobotany and Plant Ecology, University of Lodz, Łódź, Poland

2 Institute of Environmental Protection and Engineering, University of Bielsko-Biala, Willowa 2, 43-309 Bielsko-Biała, Poland et al. 2009). Some of birds e.g. woodpecker Picoides arcticus prefer almost only standing deadwood (Bull 1983; Nappi et al. 2003; Bütler et al. 2004). They are important source of tree hollows and many hollow-nesting species have preference for cavities in standing dead trees (McElhinny et al. 2005). Snags also affect phytoclimate. Under canopy of snags forest floor is more insolated due to higher amplitudes of daily temperatures (Harmon et al. 1986). Snags sometimes are treated as a transitory state between living tree and fallen bole (Angers et al. 2012). They decompose slower than logs which are in close adherence to the forest floor and soil (Boulanger and Sirois 2006). Their decay is important process in forest ecosystem dynamics. During the decomposition many other organisms become to inhabit standing deadwood. These are invertebrates (e.g. beetles), and epiphytic and/or epixylic plant species. The vascular plants are much rarer on this type of CWD. The supply of snags in forest ecosystem depends on mortality rate of trees. Snags occur at all stages of forest growth, but the factors that lead to mortality usually change as the forest ages (Neitro et al. 1985; Greif and Archibold 2000). The causes of snag formation may include suppression and competition in 
the early age of forest, whereas in the elderly stadium insect damage, fungal diseases. The other possible anthropogenic factors are air pollution, fire and improper forest management (Greif and Archibold 2000). The snag survival i.e. a time since death of living tree till fall of snag, also depends on many factors. The time can be result of species identity, size of tree, exposure to wind, climate, soil type, stand history and disturbance regime (Harmon et al. 1986; Garber et al. 2005). Additionally exposure and slope are also significant factors that increase exposure to wind (Sefidi and Mohadjer 2010).

The situation of snags i.e. altitude, slope, inclination and surrounding vegetation, their abundance may have impact on the colonization of other organisms. In this study we observed two frequent tree species namely Norway spruce Picea abies and European beech Fagus sylvatica in montane forest in southern Poland. They were examined for the presence of lichens and plants including liverworts, mosses and vascular plants. We hypothesize that species identity of snag and its trait (e.g. decomposition, cover of bark, size) as well as extrinsic factors (light conditions, altitude) have important influence on species pool inhabiting it and distinct spatio-temporal patterns of colonization can be distinguished.

\section{Material and methods}

The study was performed in Karkonosze Mts. both in protected part (Karkonosze National Park) and in its buffer zone. In both parts forest management practices were aimed to improve forest health after dieback of spruce in $80 \mathrm{~s}$ of twentieth century but they differ in intensity. At present, the average age of treestand in national park is estimated at 90 years, whereas in buffer zone - 68 years (Danielewicz et al. 2013). It has severe cold climate typical for montane area. The mean annual temperature ranges from $0.1{ }^{\circ} \mathrm{C}$ (at the top of Śnieżka Mt) to $6.9^{\circ} \mathrm{C}$ in lower parts (Fig. 1). The vegetation is distributed along an altitude gradient: foothills (up to $500 \mathrm{~m}$ a.s.1.); a lower forest montane zone (500$1000 \mathrm{~m}$ ), which includes patches of a fir-spruce mixed coniferous forest, the Abieti-Piceetum community; mixture of acidophilus beech forest i.e. the Luzulo luzuloidis-Fagetum community, and a fertile beech forest, the Dentario enneaphylliFagetum association (order Fagetalia) and planted Picea abies forest; an upper forest montane zone (1000-1250 m), where a subalpine reedgrass spruce forest - Calamagrostio villosae-Piceetum occurs (Staniaszek-Kik et al. 2016; Chmura et al. 2016). In total 180 study plots $(10 \mathrm{~m} \times 10 \mathrm{~m})$ were randomly established within occurring types of forests. The cutting areas or places of massive dieback of trees were omitted. The plots were placed only in well-developed and healthy sites (Chmura et al. 2016) belonging to four aforementioned forest communities (Table 1). The snags that were studied occurred from $522 \mathrm{~m}$ a.s.l up to $1261 \mathrm{~m}$ (Table 1). There were 80 snags: 68 of spruce and 12 of beech. The height of snags, their decomposition stage (1-4 degrees in 8-degree class scale after Holeksa (2001), modified by Zielonka and Piątek (2004), percent cover of bark, diameter at breast height (DBH) in $\mathrm{cm}$ as well as site conditions: altitude ( $\mathrm{m}$ a.s.l.), slope and shade (1-5 degree scale based on percent cover of tree canopy; Chmura et al. 2016), were measured and noted. The percent cover of plants and lichens were estimated visually (using $0,1,2,5$ and $10 \%$ intervals). Number of species (S), Shannon-Wiener diversity index $(\mathrm{H})$, and Pielou's evenness index $(\mathrm{J})$ were calculated per each snag. Nomenclature of taxa follows Fałtynowicz and Kossowska (2016) for lichens, Klama (2006) for liverworts, Ochyra et al. (2003) for mosses and vascular plants after Tutin et al. (1993). The particular species was treated as generalist when was commonly occurred in many types of substratum available in a forest e.g.: mineral soil, base of trees, bark and wood of snags, whereas specialist it is species confined to deadwood and/or trunks of living trees. Specialists are rather epixylic and/or epiphyte species. The classification of species was based primary on our observation of the organisms and the knowledge from the literature.

All statistical analyses were conducted using R software ( $R$ Core Team 2018). To explore diversity of species composition of lichens, bryophytes and vascular plants growing on snags Detrended Correspondence Analysis (DCA; Hill and Gauch 1980) was applied. This analysis was chosen due to long ecological gradients (more than 6.0 SD along first axis) using the algorithm implemented in $\mathrm{R}$ package vegan using (decorana) function (Oksanen et al. 2016). To assess the differences in species composition between two species of phorophytes a passive projection of vector representing species of snag was adopted according to (vegan::envfit) function. To examine influence of environmental factors on species composition constrained correspondence analysis (CCA) was performed by means of vegan::cca() function. In order to avoid intercorrelated factors variance inflation factor (VIF) was checked using function (vegan::vif.cca). Variance partitioning among altitude, snag traits (cover of bark, DBH, decay and height) and site conditions (slope, shade) were calculated and shown on Venn diagrams. For calculation of significance permutation test with 999 iterations was employed. The Wilcoxon sum rank test was performed to examine differences between spruce and beech snags. The Spearman rank correlation test was used to examine relationships between chosen variables.

\section{Results}

In total 663 floristic records and 99 taxa were recorded. There, lichen species were most numerous (44), followed by mosses (34), liverworts (13) and there were only 8 vascular plants (Table 2). Amongst lichens 18 species (40.9\%) were specialist 


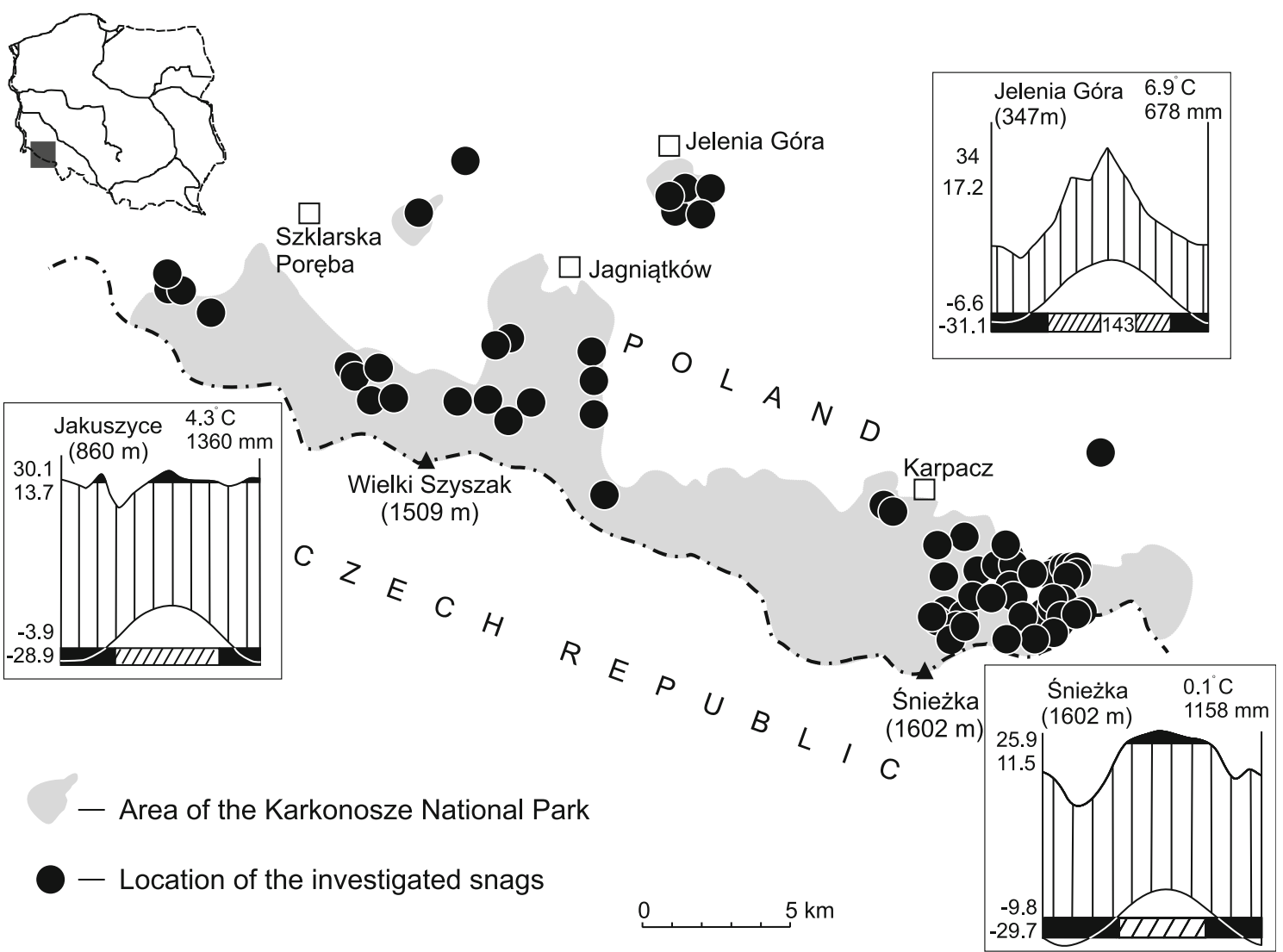

Fig. 1 The distribution of the investigated snags and climactic conditions of the area

and 26 generalists (59.1\%), whereas in vascular plants $100 \%$ of species are generalists (Table 2). In liveworts $15.4 \%$ species are specialist and $84.6 \%$ are generalist, whereas in a group of bryophytes $11.8 \%$ are specialists and $88.2 \%$ are generalists. On snags the total species richness varied from 1 to 22 taxa. The majority of floristic records were collected from spruce snags (553) and from beech snags - 110. According to DCA the species identity of snag (Picea abies or Fagus sylvatica) is significant factor in terms of species composition $\left(r^{2}=0.31\right.$, $p=0.001$, DCA vector fitting). Detailed analysis that took into account cumulative cover of species of particular groups showed that on spruce snags significantly higher number of lichens cover was recorded, in turn on beech snags higher cover of mosses was reported (Table 3). There is no significant difference in species richness but value of Shannon-Wiener index and evenness index was higher on beech snags (Table 3). The canonical correspondence analysis (CCA, Fig. 2) demonstrated that one of the most significant factors
Table 1 The characteristics of site condition and traits of spruce and beech snags as well as number of particular plots in distinguished categories of forest (Wilcoxon sum rank test, $* p<0.05, * * p<0.01$, $* * * p<0.001)$

\begin{tabular}{|c|c|c|c|c|c|c|c|c|}
\hline & \multicolumn{4}{|l|}{ Beech } & \multicolumn{4}{|l|}{ Spruce } \\
\hline & Mean & SD & MIN & MAX & Mean & SD & MIN & MAX \\
\hline Altitude [m a.s.l] & 614.8 & 99.6 & 522 & 783 & $1023.7 * * *$ & 133.4 & 688 & 1261 \\
\hline Height $[\mathrm{cm}]$ & 475.5 & 367.7 & 160.0 & 1350 & 528.3 & 353.9 & 150.0 & 1350 \\
\hline $\mathrm{DBH}[\mathrm{cm}]$ & $44.6^{* * *}$ & 15.8 & 23.0 & 70. & 22.8 & 10.9 & 11.0 & 69 \\
\hline Decay [1-8 classes] & $1 *$ & 0.7 & 1 & 3 & 2 & 0.8 & 1 & 4 \\
\hline \multirow[t]{2}{*}{ bark cover $[\%]$} & 65.4 & 30.0 & 20.0 & 95 & 56.1 & 30.7 & 0 & 100 \\
\hline & \multicolumn{2}{|l|}{ Managed } & \multicolumn{2}{|c|}{ Protected } & \multicolumn{2}{|l|}{ Managed } & \multicolumn{2}{|c|}{ Protected } \\
\hline CVP & \multicolumn{2}{|l|}{-} & \multicolumn{2}{|l|}{-} & \multicolumn{2}{|l|}{27} & \multicolumn{2}{|l|}{23} \\
\hline AP & \multicolumn{2}{|l|}{-} & \multicolumn{2}{|l|}{ - } & \multicolumn{2}{|l|}{8} & \multicolumn{2}{|l|}{3} \\
\hline $\mathrm{F}$ & \multicolumn{2}{|l|}{3} & \multicolumn{2}{|l|}{8} & \multicolumn{2}{|l|}{-} & \multicolumn{2}{|l|}{-} \\
\hline PA_F & \multicolumn{2}{|l|}{1} & \multicolumn{2}{|l|}{-} & \multicolumn{2}{|l|}{2} & \multicolumn{2}{|l|}{5} \\
\hline
\end{tabular}

CVP, Calamagrostio villosae-Piceetum; AP, Abieti-Piceetum; F, Fagetalia; PA_F, planted Picea abies forest 
Table 2 The list of species recorded on snags

\begin{tabular}{|c|c|c|c|c|c|c|}
\hline Name of species & Base of trees & Trunks of trees & Bark & Decaying wood & Specialist & Generalist \\
\hline \multicolumn{7}{|l|}{ Liverworts: } \\
\hline Barbilophozia attenuata & + & & + & + & & + \\
\hline Blepharostoma trichophyllum & + & & + & & & + \\
\hline Calypogeia integristipula & + & & + & + & & + \\
\hline C. neesiana & + & & + & & & + \\
\hline Cephalozia bicuspidata & + & & + & + & & + \\
\hline C. lunulifololia & + & & + & + & & + \\
\hline Lepidozia reptans & + & & & + & & + \\
\hline Lophocolea heterophylla & + & + & + & + & & + \\
\hline Lophozia ventricosa & + & & + & + & & + \\
\hline Metzgeria furcata & + & + & + & & + & \\
\hline Plagiochila porelloides & + & & + & & & + \\
\hline Ptilidium pulcherrimum & + & + & + & & + & \\
\hline Scapania umbrosa & + & & + & & & + \\
\hline \multicolumn{7}{|l|}{ Mosses: } \\
\hline Amblystegium juratzkanum & + & & + & & & + \\
\hline A. serpens & + & + & + & + & & + \\
\hline Brachytheciastrum velutinum & + & + & + & + & & + \\
\hline Brachythecium rutabulum & + & + & + & & & + \\
\hline B. salebrosum & + & + & + & + & & + \\
\hline Campylidium calcareum & + & & + & & & + \\
\hline Ceratodon purpureus & + & & & + & & + \\
\hline Dicranella heteromalla & + & & & + & & + \\
\hline Dicranodontium denudatum & + & & + & + & & + \\
\hline Dicranum scoparium & + & + & + & & & + \\
\hline Herzogiella seligeri & + & & + & + & & + \\
\hline Hypnum andoi & + & & + & + & & + \\
\hline H. cupressiforme & + & + & + & + & & + \\
\hline H. cupressiforme var. filiforme & & + & + & & + & \\
\hline H. pallescens & + & & + & & & + \\
\hline Mnium hornum & + & & + & + & & + \\
\hline Orthodicranum montanum & + & + & + & + & & + \\
\hline Orthotrichum pumilum & & + & + & + & + & \\
\hline Paraleucobryum longifolium & + & & + & + & & + \\
\hline Plagiomnium cuspidatum & + & & & + & & + \\
\hline Plagiothecium curvifolium & + & & + & + & & + \\
\hline P. laetum & + & + & + & + & & + \\
\hline P. nemorale & + & & & + & & + \\
\hline P. platyphyllum & + & & & + & & + \\
\hline P. succulentum & + & & + & & & + \\
\hline Pohlia nutans & + & + & + & + & & + \\
\hline Polytrichastrum formosum & + & & + & + & & + \\
\hline Pterigynandrum filiforme & & + & + & + & + & \\
\hline Rosulabryum moravicum & + & & + & & & + \\
\hline Sanionia uncinata & + & & + & + & & + \\
\hline Sciuro-hypnum reflexum & + & & + & & & + \\
\hline S. starkei & + & & + & + & & + \\
\hline Tayloria serrata & + & & + & & + & \\
\hline Tetraphis pellucida & + & + & + & + & & + \\
\hline \multicolumn{7}{|l|}{ Lichens: } \\
\hline Bacidina arnoldiana & + & & + & + & + & \\
\hline Biatora amaurospoda & + & + & + & + & + & \\
\hline Candelariella reflexa & & + & + & & + & \\
\hline C. vitellina & + & & + & & + & \\
\hline Chaenotheca ferruginea & & + & & + & + & \\
\hline C. trichialis & & + & + & & + & \\
\hline Cladonia deformis & + & & + & & & + \\
\hline C. digitata & + & & + & + & & + \\
\hline C. fimbriata & + & & + & & & + \\
\hline C. ochrochlora & + & & + & + & & + \\
\hline C. polydactyla & + & & + & & & + \\
\hline Cladonia sp. & + & & + & + & & + \\
\hline Dimerella pineti & + & & + & & + & \\
\hline
\end{tabular}


Table 2 (continued)

\begin{tabular}{|c|c|c|c|c|c|c|}
\hline Name of species & Base of trees & Trunks of trees & Bark & Decaying wood & Specialist & Generalist \\
\hline Graphis scripta & & + & + & & + & \\
\hline Hypocenomyce caradocensis & + & + & + & + & + & \\
\hline H. scalaris & + & + & + & + & & + \\
\hline Hypogymnia physodes & + & + & + & + & & + \\
\hline Lecania cyrtella & & + & & + & + & \\
\hline Lecanora conizaeoides & + & + & + & + & + & \\
\hline L. glabrata & & + & + & & + & \\
\hline L. pulicaris & & + & + & & + & \\
\hline Lecidella elaeochroma & & + & + & & + & \\
\hline Lepraria elobata & + & + & + & + & & + \\
\hline Lepraria incana & + & & + & & & + \\
\hline L. jackii & + & + & + & + & & + \\
\hline L. lobificans & + & & + & + & & + \\
\hline Lepraria sp. & + & + & + & + & & + \\
\hline L. toensbergiana & + & & + & & & + \\
\hline Melanelia subaurifera & & + & + & & & + \\
\hline Micarea botryoides & + & + & + & & & + \\
\hline M. peliocarpa & + & & + & & & + \\
\hline M. prasina & + & + & + & + & & + \\
\hline Omphalina umbellifera & + & & & + & + & \\
\hline Opegrapha varia & & + & + & & + & \\
\hline Parmeliopsis ambigua & & + & + & + & & + \\
\hline Pertusaria amara & & + & + & & & + \\
\hline P. leioplaca & & + & + & & + & \\
\hline Placynthiella dasaea & + & & + & + & & + \\
\hline P. icmalea & + & & + & + & & + \\
\hline Platismatia glauca & & + & + & & & + \\
\hline Pseudevernia furfuracea & & + & + & + & & + \\
\hline Scoliciosporum chlorococcum & & + & & + & & + \\
\hline Strangospora pinicola & & + & & + & + & \\
\hline Trapeliopsis flexuosa & + & + & + & + & & + \\
\hline \multicolumn{7}{|l|}{ Vascular plants: } \\
\hline Calamagrostis arundinacea & + & & & + & & + \\
\hline C. villosa & + & & & + & & + \\
\hline Deschampsia flexиosa & + & & + & & & + \\
\hline Dryopteris carthusiana & + & & + & & & + \\
\hline Fagus sylvatica & + & & & + & & + \\
\hline Oxalis acetosella & + & & + & + & & + \\
\hline Senecio nemorensis ssp. fuchsii & + & & & + & & + \\
\hline Trientalis europaea & + & & + & + & & + \\
\hline Vaccinium myrtillus & + & & + & + & & + \\
\hline
\end{tabular}

in terms of impact on species composition is altitude (pseudo$\mathrm{F}=4.77, p=0.001$ ), bark cover ( $p$ seudo- $\mathrm{F}=1.72, p=0.008$ ), $\mathrm{DBH}$ (pseudo-F $=3.24, \mathrm{p}=0.001$ ) and height of snags (Pseudo-F $=1.78, p=0.004$ ). The analyzed variables explain only $22.1 \%$ of variance in species composition (Fig. 3). Taking into account combined snags the number of species is positively correlated with $\mathrm{DBH}(\mathrm{rs}=0.39, p<0.001)$, whereas decomposition stage, presence of bark, height of snag are not significant factors. The total species richness increases also with altitude ( $\mathrm{rs}=0.24, p=0.02)$ (Fig. 4). Taking into account particular groups of species lichens were negatively correlated with altitude but in turn mosses were positively correlated. The cover of liverworts and mosses were negatively correlated with height of snags, whereas lichens were positively correlated with DBH. The bark cover was significant for lichens which were positively correlated with it (Table 4).

\section{Discussion}

\section{Conditions of snags presence}

In this study within study plots we found 80 snags and all of them were colonized by lichens and in some cases by plants as well. It is relatively small number when compared to all available snags. Per $100 \mathrm{~m}^{2}$ plot from 0 to 5 snags were recorded. In temperate European forests the density of snags per hectare ranges from 4.0 (Perry and Thill 2013) to ca 100 (Marage and Lemperiere 2005). The low number of studied snags can affect results of found snag flora. For instance overall species richness of bryophytes depends on CWD abundance and diversity (Müller et al. 2015). The total species pool of plant and lichens inhabiting snags depend on observed number of snags in the area. Another factor that can have an impact on 
Table 3 The descriptive statistics of combined percent cover of particular groups of plants and lichens on snags (Wilcoxon sum rank test, $* p<0.05, * * p<0.01$, $* * * p<0.001)$

\begin{tabular}{|c|c|c|c|c|c|c|c|c|}
\hline & \multicolumn{4}{|l|}{ Beech } & \multicolumn{4}{|l|}{ Spruce } \\
\hline & Mean & $\mathrm{SD}$ & MIN & MAX & Mean & $\mathrm{SD}$ & MIN & MAX \\
\hline Lichens & 10.9 & 15.7 & 1 & 50 & $32.3 * * *$ & 21.17 & 0 & 85 \\
\hline Liverworts & 1.8 & 1.9 & 0 & 5 & 1.3 & 1.4 & 0 & 5 \\
\hline Mosses & $12.5^{* * *}$ & 11.0 & 3 & 50 & 2.7 & 2.9 & 0 & 20 \\
\hline Vascular plants & 0.5 & 0.9 & 1 & 3 & 0.4 & 0.9 & 0.2 & 5 \\
\hline Total cover & 25.5 & 18.41 & 4.00 & 58.00 & 35.74 & 23.13 & 1.00 & 100.00 \\
\hline S & 9.7 & 5.7 & 4 & 22 & 8.2 & 3.9 & 1 & 19 \\
\hline $\mathrm{H}$ & $1.9 * *$ & 0.5 & 0.8 & 2.6 & 1.4 & 0.6 & 0 & 2.5 \\
\hline $\mathrm{J}$ & $0.9 * * *$ & 0.1 & 0.6 & 1 & 0.7 & 0.3 & 0 & 1 \\
\hline
\end{tabular}

observation of species colonizing snags is species identity of tree. In the present study spruce snags prevailed. In the years of 1960-1980 massive decline of Picea abies stands were observed due to i.e. air pollution and fungal diseases. At present the main drivers of dying out of spruce is climate change and emissions of $\mathrm{SO}_{2}$ and NOx (Jadczyk 2009; Modrzyński 2003; Korzybski et al. 2013). Aforementioned processes contributed to snag recruitment, however, the dominance of spruce in snags is first of all a result of the overall dominance of this tree in Karkonosze Mts. The percentage of spruce Picea abies in the treestand is estimated at $90 \%$ in this area including the lower montane belt where it occupies $85 \%$ of treestand despite it is natural habitat for beech forests (Danielewicz et al. 2013). The physicochemical properties of the bark and wood vary among tree species (Petrillo et al. 2015) therefore it can be expected that it can affect colonizing lichens and plants. Bark of beech is less acid (5.0-5.4) than spruce (3.6-3.9) (Fengel and Wegener 1983; Marmor and Randlane 2007).

\section{Characterization of epixylic flora}

Many of found species in this study are generally regarded as epixylic thus their presence is not surprising (HeilmannClausen et al. 2014). In total 24 species were classified as
Fig. 2 The ordination of snags along the first two axes of Detrended Correspondence Analysis (DCA; $\lambda_{1}=0.74 \lambda_{2}=$ 0.67 ; grey circles - spruce snags, empty squares - beech snags). DCA explain $7.8 \%$ and $14.8 \%$ of species variance (a). Biplot of Canonical Correspondence Analysis (CCA, $\lambda_{1}=0.61 \lambda_{2}=$ 0.43 ) showing species and environmental factors on 80 snags. The first four letters indicate genus name the next four letters indicate species name. The most frequent species are shown (b)

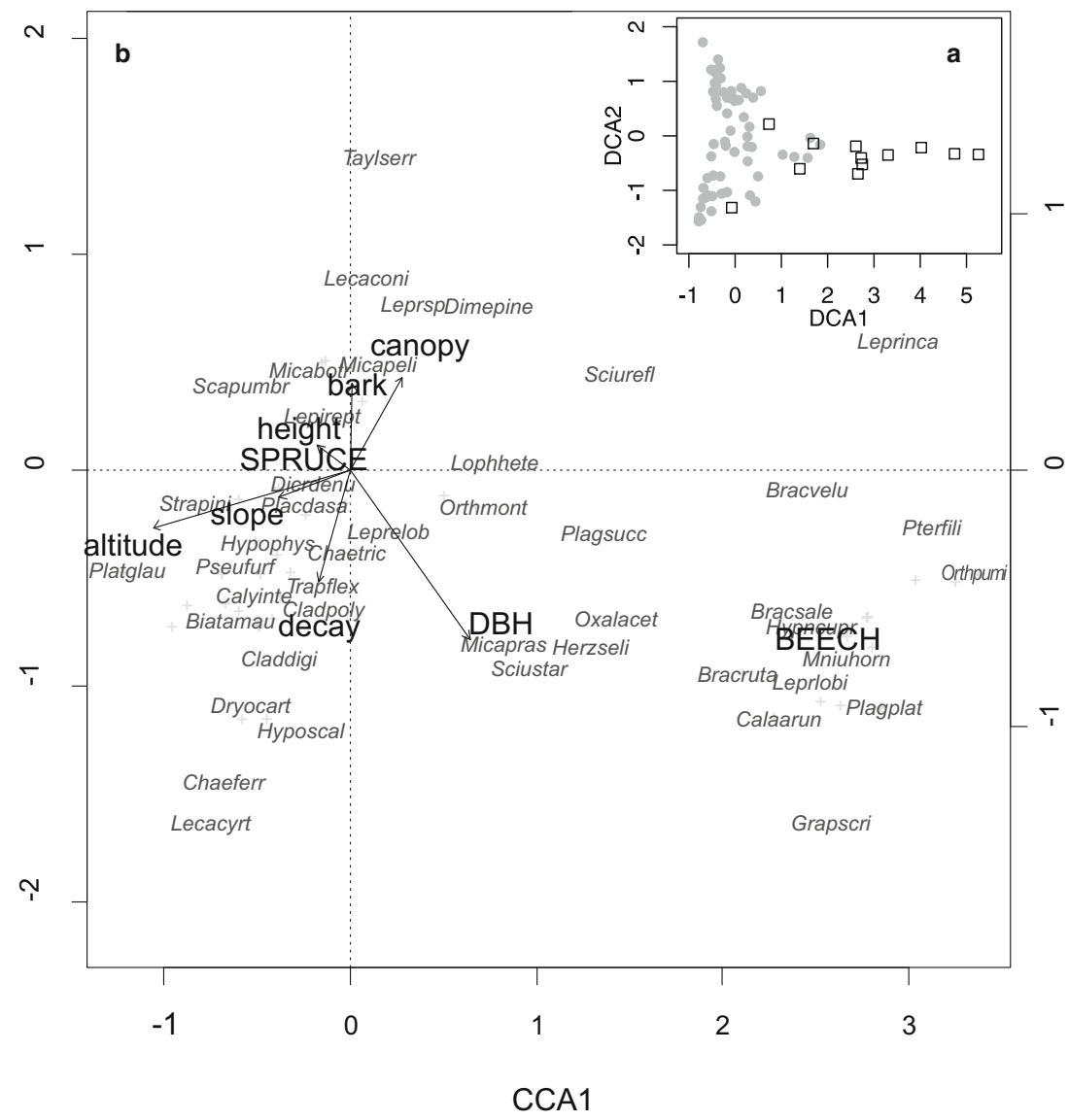




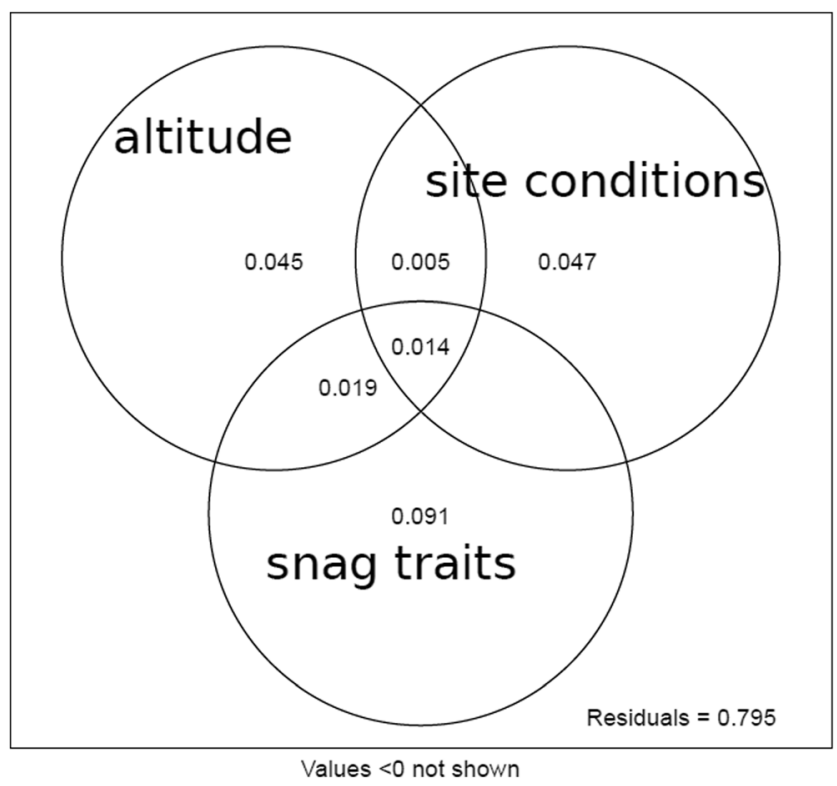

Fig. 3 The explained variance partitioning in three groups of factors. Abbreviations: Altitude (elevation a.s.l. m), site conditions: slope, shade, snag trails: height, DBH, bark cover, decomposition class

specialists. Amongst specialist lichens species as eg. Chaenotheca ferruginea, Dimerella pineti, Graphis scripta, Hypocenomyce caradocensis, Lecanora conizaeoides, $L$. glabrata and L. pulicaris are considered as epiphyte species but also occasionally found on deadwood. Majority of epixylic species are former epiphyte that survived after death of tree. A lot species encountered on permanent plots situated in healthy sites in Karkonosze National Park (Kossowska et al. 2007) were not found in this study. The lichen community is dominated rather by common and wide niche species. Liverworts are also usually quite common. These are Metzgeria furcata and Ptilidium pulcherrimum epiphytic liverworts, known to occur on bark of trees (Górski 2006). As regards mosses
Orthotrichum pumilum and $H$. cupressiforme var. filiforme are known as obligate epiphyte species thus their preference to microhabitats associated with trunks, bark make them specialist species (Kürschner et al. 2012; Vanderpoorten et al. 2004). In turn, vascular plants are hardly to be regarded as specialists. Only few species are present on snags and in general on deadwood they most frequently are to be found on logs. For them deadwood an additional substratum (Harmon et al. 1986). The differences in species composition of colonizing species observed between two tree species are caused by several factors. One of them is altitude and environmental factors associated with it: temperature, moisture, epigeic vegetation. Total species richness of colonizing flora and DBH of snags increase with increasing altitude what is caused by shift of distribution of beech and spruce (Grytnes et al. 2006; Spitale 2016). In our study higher cover of bryophytes was observed on beech snags which generally are at lower elevation than spruce (Table 1). It contradicts the results by Goia and Gafta (2018) who claimed there was no consistent relationship between bryophyte preference to beech deadwood vs spruce deadwood and altitude. As lichens are concerned they were more frequent on spruce logs which mostly occurred at higher altitude. It is congruent with study by Vondrák et al. (2018) who observed the highest alpha diversity of lichens at the highest study plot in Carpathians. In turn, Ardelean et al. (2015) claimed that for lichen species on deadwood, the vegetation type had more significant effect on species richness than altitude, management, slope and aspect. In our case they were more abundant on spruce snags which were more frequent in coniferous forests what partially confirm it. We found that lichens in general had higher cover than mosses. In spruce snags mean cover was more than $32 \%$ whereas on beech snags about $10 \%$ - a little lower than cover of mosses. Apart from the dominance of lichens in terms of species richness (they consitute $40 \%$ of total snag flora) their higher abundance also
Fig. 4 The Spearman rank correlation analysis between $\mathrm{DBH}$, altitude and number of species found on snags
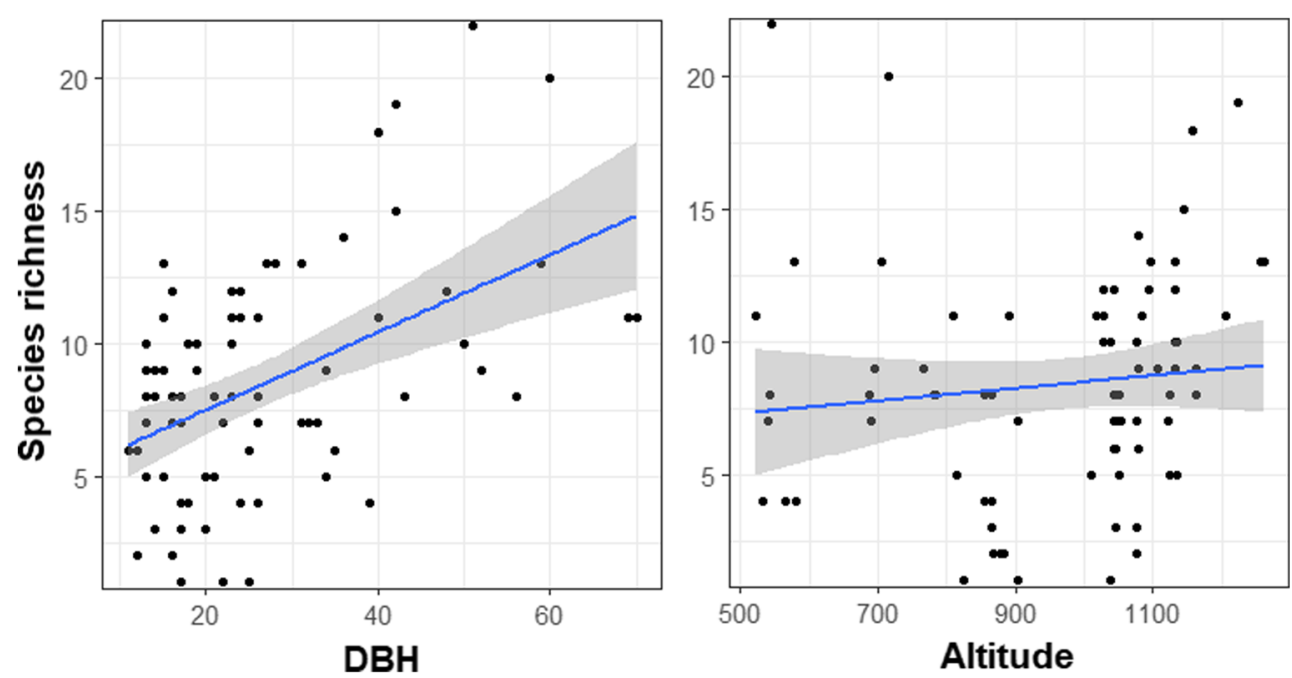
Table 4 The Spearman rank intercorrelations of particular groups and snag traits and altitude $* p<0.05, * * p<0.01, * * * p<0.001$, NS - nonsignificant)

\begin{tabular}{llllllllll}
\hline & Altitude & Height & DBH & Decay & Bark cover & Lichens & Liverworts & Mosses & Vascular plants \\
\hline Lichens & $0.43^{* * *}$ & NS & -0.14 & NS & $0.23^{*}$ & - & NS & $-0.36^{* * *}$ & NS \\
Liverworts & & $-0.24^{*}$ & NS & NS & NS & NS & & $0.30^{* *}$ & NS \\
Mosses & $-0.36^{* * *}$ & -0.34 & 0.47 & NS & NS & $-0.36^{* * *}$ & $0.30^{* *}$ & - & NS \\
Vascular plants & NS & NS & $0.38^{* * *}$ & NS & NS & NS & NS & NS & NS \\
\hline
\end{tabular}

confirm the fact that snags are preferred by lichens. In other work Machowska (2015) found 28 lichen species that 17 were found on spruce snags in Karkonosze National Park. Seven species were also reported in the present study e.g. Cladonia digitata, Hypocenomyce caradocensis, H. scalaris, Lecanora conizaeoides, Lepraria jackii whereas 32 were new e.g. Cladonia fimbriata, Frutidella pullata, Pseudevernia furfuracea.

\section{Influence of snag properties on epixylic flora}

Amongst CWD types lichens most frequently occur on snags (Humphrey et al. 2002 and literature cited therein). However, our results are not in concordance with their finding that lichens are more frequent on decorticate snags. In our case we took into account cover instead of species richness but despite this our result is the opposite because cover of lichens was positively correlated with bark cover (Samuelsson et al. 1994). For bryophytes, which combined number of liverworts and mosses amounted to 47, snags are not preferable type of substratum among CWD. Stumps harbour a greater species pool of bryophytes than logs and snags. The probable reasons are bigger moisture, higher surface area of contact with soil and higher avilaibility of microsites on hardwood and softwood with diversified decay (Müller et al. 2015). It is believed that epixylic mosses and liverworts are weak competitors and thus they have highest cover of debarked trunks because they avoid competiton with lichens on bark. One of the most frequent moss species is Tetraphis pellucida typical epixylic species which also frequentely occur on logs (Machowska 2015). We observed negative correlation between covers of mosses and lichens what is congruent with known pattern of colonization of lichens and bryophytes.

Other factors are important e.g. size of snag and decay. The mosses were positively correlated with DBH of snags but negatively with height of snags. In the case of living trees this would be impossible because usually height of tree increases with DBH but snags during decomposition can be broken. The higher preference of mosses for large diameter was observed in work by Humphrey et al. (2002) but for logs and stumps. Bearing in mind that many species occur both on snags and logs this pattern is also true for snags. Our results confirm that some liverworts species that are considered as late epixylics are associated with more advanced phases of decay. These are: Blepharostoma trichophyllum, Cephalozia lunulifololia, Lepidozia reptans (Söderström 1988). According to Machowska (2015) low fraction of liverworts can be encounterd on snags. She found only 3 species, whereas in this study there were 13 .

The vascular plants was the most species-poor group comprising only 8 species. As many studies showed there are no mandatory epixylic vascular plants. For this group CWD is not important substratum. Much more number of species occur on logs but they have contact with soil and it is easier to colonize. Moreover, logs are more moist and can accumulate humus during decomposition enabling penetration by vascular plants (Harmon et al. 1986). Snags due to dry wood, large distance to ground, vertical position are unfavourable substratum for vascular plants to be colonized. Nevertheless, species that occur e.g. Oxalis acetosella, Vaccinium myrtillus, Calamagrostis villosa are frequntely observed on many types of CWD elements were also reported in other studies (Zielonka and Piatek 2004; Nowińska et al. 2009; Kirchner et al. 2011). The vascular plants showed preference for snags with larger DBH what is in with line with the same pattern for logs (Staniaszek-Kik et al. 2014; Chećko et al. 2015; Chmura et al. 2018). It is probably a result of higher diversity of niches (cavities, crevices, humus) and more stable conditions. Larger snags can decompose slower than smaller ones (Harmon et al. 1986).

Almost $20 \%$ of species variation is explained by studied factors and among them snag traits seem to play the most crucial role. The other important variables that can have an impact on shaping snag communities are associated with species pool of vascular plants growing on mineral soil, epigeic bryophytes and lichens inhabiting living trees. From these groups of organisms snag-inhabiting taxa recruit. Previous works (Staniaszek-Kik et al. 2014, 2016; Chmura et al. 2016) revealed importance of plant communities in colonization of logs by vascular plants. It can be expected that the same mechanisms take place.

\section{Conclusions}

The communities occurring on snags are rather species-poor what is reflected by impact of snag attributes on species 
composition. The neighborhood, especially factors related to altitude and vegetational gradient are important. Despite of some observed patterns in colonization of snags they are significant habitat only for lichens what can be confirmed by number of found species on snags and comparison of data from literature.

Acknowledgments We would like to thank the Reviewers for valuable comments and suggestions on our manuscript.

\section{Compliance with ethical standards}

Conflict of interest The authors declare that they have no conflict of interest.

Open Access This article is distributed under the terms of the Creative Commons Attribution 4.0 International License (http:// creativecommons.org/licenses/by/4.0/), which permits unrestricted use, distribution, and reproduction in any medium, provided you give appropriate credit to the original author(s) and the source, provide a link to the Creative Commons license, and indicate if changes were made.

Publisher's note Springer Nature remains neutral with regard to jurisdictional claims in published maps and institutional affiliations.

\section{References}

Angers VA, Drapeau P, Bergeron Y (2012) Mineralization rates and factors influencing snag decay in four north American boreal tree species. Can J For Res 42(1):157-166

Ardelean IV, Keller C, Scheidegger C (2015) Effects of management on lichen species richness, ecological traits and community structure in the Rodnei Mountains National Park (Romania). PLoS One 10(12): e0145808. https://doi.org/10.1371/journal.pone.0145808

Boulanger Y, Sirois L (2006) Postfire dynamics of black spruce coarse woody debris in northern boreal forest of Quebec. Can J For Res 36(7):1770-1780

Bull EL (1983) Longevity of snags and their use by woodpeckers. In: Davis JW, Goodwin GA, Ockenfels RA (tech coordinators). Proceedings of the symposium: snag habitat management. Gen. Tech. Rep. GTR-RM-99. Fort Collins, CO: Rocky Mountain Research Station, Forest Service, US Department of Agriculture, pp. 64-67

Bütler R, Angelstam P, Ekelund P, Schlaepfer R (2004) Dead wood threshold values for the three-toed woodpecker presence in boreal and sub-alpine forest. Biol Conserv 119(3):305-318

Chećko E, Jaroszewicz B, Olejniczak K, Kwiatkowska-Falińska AJ (2015) The importance of coarse woody debris for vascular plants in temperate mixed deciduous forests. Can J For Res 45(9):1154-1163

Chmura D, Żarnowiec J, Staniaszek-Kik M (2016) Interactions between plant traits and environmental factors within and among montane forest belts: a study of vascular species colonising decaying logs. For Ecol Manag 379:216-225

Chmura D, Żarnowiec J, Staniaszek-Kik M (2018) Comparison of traits of non-colonized and colonized decaying logs by vascular plant species. iForest 11:11-16

Danielewicz W, Raj A, Zientarski J (2013) Ekosystemy leśne [Forest ecosystems]. In: Knapik R, Raj A (eds) Przyroda Karkonoskiego Parku Narodowego. [The nature of Karkonosze National Park], Karkonoski Park Narodowy, pp 279-301 (in Polish)
Drapeau P, Nappi A, Imbeau L, Saint-Germain M (2009) Standing deadwood for keystone bird species in the eastern boreal forest: managing for snag dynamics. For Chron 85(2):227-234

Faltynowicz W, Kossowska M (2016) The lichens of Poland. A fourth checklist. Acta Bot Siles Monogr 8:3-122

Fengel D, Wegener G. (eds) (1983) Wood: chemistry, ultrastructure, reactions. Walter de Gruyter

Garber SM, Brown JP, Wilson DS, Maguire DA, Heath LS (2005) Snag longevity under alternative silvicultural regimes in mixed-species forests of Central Maine. Can J For Res 35:787-796

Goia I, Gafta D (2018) Beech versus spruce deadwood as forest microhabitat: does it make any difference to bryophytes? Plant Biosystems:1-8. https://doi.org/10.1080/11263504.2018.1448011

Górski P (2006) Liverworts of the nature reserves in Wielkopolska. 2. "Olbina" Rocz AR Pozn Bot Stec 10:97-102

Greif GE, Archibold OW (2000) Standing-dead tree component of the boreal forest in Central Saskatchewan. For Ecol Manag 131(1-3):37-46

Grytnes JA, Heegaard E, Ihlen PG (2006) Species richness of vascular plants, bryophytes, and lichens along an altitudinal gradient in western Norway. Acta Oecol 29:241-246

Harmon ME, Franklin JF, Swanson FJ, Sollins P, Gregory SV, Lattin JD et al (1986) Ecology of coarse woody debris in temperate ecosystems. Adv Ecol Res 15:133-302

Heilmann-Clausen J, Aude E, van Dort K, Christensen M, Piltaver A, Veerkamp $\mathrm{M}$ et al (2014) Communities of wood-inhabiting bryophytes and fungi on dead beech logs in Europe-reflecting substrate quality or shaped by climate and forest conditions? J Biogeogr 41(12):2269-2282

Hill MO, Gauch HG (1980) Detrended correspondence analysis: an improved ordination technique. Vegetatio 42:47-58

Holeksa J (2001) Coarse woody debris in a Carpathian subalpine spruce forest. Forstwiss Centbl 120:256-270

Humphrey JW, Davey S, Peace AJ, Ferris R, Harding K (2002) Lichens and bryophyte communities of planted and semi-natural forests in Britain: the influence of site type, stand structure and deadwood. Biol Conserv 107(2):165-180

Jadczyk P (2009) Natural effects of large-area forest decline in the Western Sudeten. Environ Prot Eng 35(1):49-56

Kirchner K, Kathke S, Bruelheide H (2011) The interaction of gap age and microsite for herb layer species in a near-natural spruce forest. $\mathrm{J}$ Veg Sci 22(1):85-95

Klama H (2006) Systematic catalogue of polish liverwort and hornwort taxa. In: Szweykowski J (ed) An annotated checklist of polish liverworts and hornworts. Szafer Institute of Botany. Polish Academy of Sciences, Kraków, pp 83-100

Korzybski D, Mionskowski M, Dmyterko E, Bruchwald A (2013) Stopień uszkodzenia świerka, jodły i modrzewia w Sudetach Zachodnich (degree of damage to spruce, fir and larch stands in the Western Sudetes). Sylwan 157(2):104-112

Kossowska M, Szczepańska K, Fałtynowicz W, Jando K, Kowalewska A, Dimos M (2007) Różnorodność gatunkowa porostów epifitycznych na stałych powierzchniach monitoringowych w Karkonoskim Parku Narodowym. Parki Nar Rez Przyr 26(1):3-16

Kürschner H, Kırmacı M, Erdağ A, Batsatsashvili K, Parolly G (2012) Ecology and life strategies of epiphytic bryophyte communities from the Arcto-tertiary relict forests of the black and Caspian Sea areas. Nova Hedwigia 94(1):31-65

Machowska A (2015) Porosty, mchy i wątrobowce występujące na martwych świerkach Picea abies w reglu górnym Śląskiego Grzbietu (Karkonoski Park Narodowy). Acta Bot Siles 11:87-100

Marage D, Lemperiere G (2005) The management of snags: a comparison in managed and unmanaged ancient forests of the southern French Alps. Ann For Sci 62(2):135-142

Marmor L, Randlane T (2007) Effects of road traffic on bark pH and epiphytic lichens in Tallinn. Folia Cryptogam Est 43:23-37 
McElhinny C, Gibbons P, Brack C, Bauhus J (2005) Forest and woodland stand structural complexity: its definition and measurement. For Ecol Manag 218(1-3):1-24

Modrzyński J (2003) Defoliation of older Norway spruce (Picea abies/L./ karst.) stands in the polish Sudety and Carpathian mountains. For Ecol Manag 181(3):289-299

Müller J, Boch S, Blaser S, Fischer M, Prati D (2015) Effects of forest management on bryophyte communities on deadwood. Nova Hedwigia 100(3-4):423-438

Nappi A, Drapeau P, Giroux JF, Savard JPL (2003) Snag use by foraging black-backed woodpeckers (Picoides arcticus) in a recently burned eastern boreal forest. Auk 120(2):505-511

Neitro WA, Binkley VW, Cline SP, Mannan RW, Marcot BG, Taylor D, Wagner FF (1985) Snags (wildlife trees). In: Brown ER (ed) Management of Wildlife and Fish Habitats in forests of Western Oregon and Washington. USDA For. Serv. Pacific Northwest Region, Portland, pp 26-34

Nowińska R, Urbański P, Szewczyk W (2009) Species diversity of plants and fungi on logs of fallen trees of different species in oak-hornbeam forests. Roczn AR Pozn Bot Stec 13:109-124

Ochyra R, Żarnowiec J, Bednarek-Ochyra H (2003) Census catalogue of Polish mosses. Biodiversity of Poland. Vol. 3. W. Szafer Institute of Botany, Polish Academy of Sciences, Kraków

Oksanen J, Blanchet FG, Kindt R, Legendre P, Michin PR, O'Hara RB, Simpson GL, Solymos P, Henry M, Stevens H, Wagner H (2016) "vegan" 2.4.4. Community Ecology Package. URL http://CRAN.Rproject.org/package=vegan, Accessed September, 2018

Perry RW, Thill RE (2013) Comparison of snag densities among regeneration treatments in mixed pine-hardwood forests. Can J For Res 43(7):619-626

Petrillo M, Cherubini P, Sartori G, Abiven S, Ascher J, Bertoldi D, Camin F, Barbero A, Larcher R, Egli M (2015) Decomposition of Norway spruce and European larch coarse woody debris (CWD) in relation to different elevationand exposure in an Alpine setting. iForest 9: $154-164$
R Core Team (2018) R: A language and environment for statistical computing. R Foundation for Statistical Computing, Vienna URL https://www.R-project.org/ . Accessed 23 March 2018

Samuelsson J, Gustafsson L, Ingelög T (1994) Dying and dead trees. A review of their importance for biodiversity. Uppsala

Sefidi K, Mohadjer MRM (2010) Snag dynamic in a mixed beech forest. Iranian J For Poplar Res 18(4):517-526

Söderström L (1988) Sequence of bryophytes and lichens in relation to substrate variables of decaying coniferous wood in northern Sweden. Nor J Bot 8(1):89-97

Spitale D (2016) The interaction between elavational gradient and substratum reveals how bryophytes respond to the climate. J Veg Sci 27: 844-853

Staniaszek-Kik M, Żarnowiec J, Chmura D (2014) Colonization patterns of vascular plant species on decaying logs of Fagus sylvatica L. in a lower mountain forest belt: a case study of the Sudeten Mountains (Southern Poland). Appl Ecol Environ Res 12(3):601-613

Staniaszek-Kik M, Żarnowiec J, Chmura D (2016) The vascular plant colonization on decaying Picea abies logs in Karkonosze mountain forest belts: the effects of forest community type, cryptogam cover, $\log$ decomposition and forest management. Eur J For Res 135(6): $1145-1157$

Tutin TG, Burges NA, Chater AO, Edmondson JR., Heywood VH, Moore DM. et al (1993) Flora europaea, ed. 2, 1. Cambridge

Vanderpoorten A, Engels P, Sotiaux A (2004) Trends in diversity and abundance of obligate epiphytic bryophytes in a highly managed landscape. Ecography 27(5):567-576

Vondrák J, Malíček J, Palice Z, Bouda F, Berger F, Sanderson N et al (2018) Exploiting hot-spots; effective determination of lichen diversity in a Carpathian virgin forest. PLoS One 13(9):e0203540. https:// doi.org/10.1371/journal.pone.0203540

Zarnowitz JE, Manuwal DA (1985) The effects of forest management on cavity-nesting birds in northwestern Washington. J Wildl Manag 49(1):255-263

Zielonka T, Piątek G (2004) The herb and dwarf shrubs colonization of decaying $\operatorname{logs}$ in subalpine forest in the polish Tatra Mountains. Plant Ecol 172(1):63-72 